\title{
Judicialization of administrative measures to tackle the Covid-19 pandemic in Brazil $^{9}$
}

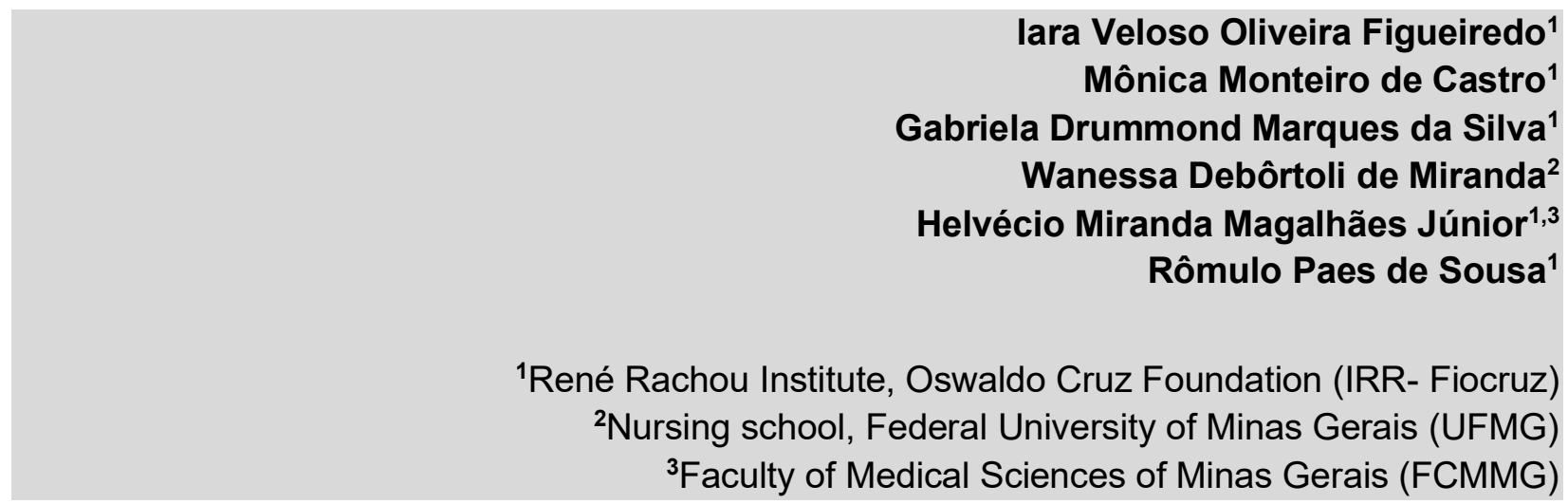

This article studied the judicialization lawsuits related to the pandemic of the new coronavirus, within the scope of Administrative Law. The cases that reached the Brazilian Federal Supreme Court (FSC), available at the "Painel de Ações COVID-19", were analyzed, as well as a sample of the cases that reached the state courts, obtained through journalistic reports, consolidated on the "Consultor Jurídico" website. Descriptive analysis and content analysis techniques were used, in the thematic mode, for both sources of information. The following variables were analyzed: procedural classes groups, procedural classes, main subject, notification date, time until the first decision, decisions, decisions groups, and total of cases archived remotely. Near $34 \%$ of the actions referred to the flexibilization or tightening of free movement, restrictive measures on and the opening of commerce and services, and another $34 \%$ referred to budgeting issues, mainly dealing with the suspension of state debts and untying resources to combat the pandemic. The median time until the first decision made by the FSC was less than five days for all categories. The judicialization of COVID-19 pointed out already known flaws in public health and social policies in Brazil, and it can encourage a lot of actions, both by the Legislative and the Executive, to mitigate these problems. This article demonstrates the importance of observing the responses brought by the judicialization, and of the dialogue between the three powers, to deal with the demands of the pandemic better and with several other demands of society.

Key words: COVID-19, judicialization of health, Administrative Law.

${ }^{9}$ DOI: http://dx.doi.org/10.21874/rsp.v71i0.4998

ISSN: 0034-9240 | E-ISSN: 2357-8017

(ㅇ)(1) Submitted: August 16, 2020. Published: August 20, 2020. 


\section{Judicialização das medidas administrativas de combate à pandemia do COVID-19 no Brasil}

Este artigo estudou os processos de judicialização relacionados à pandemia do novo coronavírus, no âmbito do Direito Administrativo. Foram analisados os processos que chegaram até o Supremo Tribunal Federal (STF), disponibilizados no Painel de Ações COVID-19, e uma amostra dos processos que chegaram aos tribunais estaduais, obtida através de reportagens jornalísticas, consolidadas no Portal Consultor Jurídico. Foram utilizadas técnicas de análise descritiva e de análise de conteúdo, na modalidade temática, para as duas fontes de informação. Foram analisadas as seguintes variáveis: grupo de classes processuais, classes processuais, assunto principal, data de autuação, tempo até a primeira decisão, decisões, grupo de decisões e total de processos baixados por meio remoto. Cerca de $34 \%$ das ações se referiam à flexibilização ou ao endurecimento das medidas restritivas de circulação da população e à abertura do comércio e de serviços, e outros $34 \%$ a questões orçamentárias, versando principalmente sobre a suspensão de dívidas dos estados e sobre a desvinculação de recursos para o combate à pandemia. A mediana do tempo até a primeira decisão tomada pelo STF foi inferior a cinco dias para todas as categorias. A judicialização da COVID-19 apontou falhas já conhecidas nas políticas públicas de saúde e sociais no Brasil e pode impulsionar diversas atitudes, tanto do Legislativo quanto do Executivo, para mitigar esses problemas. Este artigo demonstra a importância de observar as respostas trazidas pela judicialização, e o diálogo entre os três poderes, para melhor lidar com as demandas da pandemia e também com diversas outras demandas da sociedade.

Palavras-chave: COVID-19, judicialização da saúde, Direito Administrativo.

\section{Título: Judicialización de medidas administrativas para combatir la pandemia del COVID- 19 en Brasil}

En este artículo se estudiaron los procesos judiciales del nuevo coronavirus en el Derecho Administrativo. Se analizaron los procesos que llegaron al Supremo Tribunal Federal (STF), disponible en el "Painel de Ações COVID-19", y una muestra de los casos de los tribunales estatales, obtenidos a través de informes periodísticos, consolidados en el portal "Consultor Jurídico". Se utilizaron técnicas de análisis descriptivo y de contenido, en la modalidad temática, para ambas fuentes. Se analizaron las variables grupo de tipos procesales, tipos procesales, tema principal, fecha de actuación, tiempo hasta la primera decisión, decisiones, grupo de decisiones y total de procesos descargados de forma remota. Alrededor del $34 \%$ de las acciones se referían a la flexibilización o endurecimiento de las medidas restrictivas de circulación y a la apertura del comercio y de los servicios, y otro $34 \%$ a cuestiones presupuestarias, principalmente la suspensión de las deudas de los estados y la desvinculación de los recursos para el combate de la pandemia. El tiempo mediano hasta la primera decisión tomada por el STF fue de menos de cinco días para todas las categorías. La judicialización de la COVID-19 señaló las fallas ya conocidas de las políticas públicas de salud y sociales en Brasil y puede impulsar actitudes de los Poderes Legislativo y Ejecutivo. Los resultados demuestran la importancia de observar las respuestas aportadas por la judicialización, y también el diálogo entre los tres poderes, a fin de afrontar mejor las demandas de la pandemia y también diversas otras demandas de la sociedad. 
Palabras clave: COVID-19, judicialización de la salud, Derecho Administrativo. Introduction

The COVID-19 pandemic is the largest health and humanitarian emergency that has occurred in the world in the past hundred years. Having started in December 2019 in Wuhan, China (ZHU et al., 2020), the new coronavirus has spread rapidly across the globe, causing thousands of deaths, and creating a great impact in the health, economic, and political fields.

To tackle COVID-19, many countries are using a combination of containment and mitigation activities to prevent simultaneous increases in cases, to level the demand for hospital beds and to protect the most vulnerable individuals from infection, including the elderly and people with comorbidities. Actions to achieve these goals vary between countries, and they are based on national risk assessments that, for the most part, include estimated numbers of patients requiring hospitalization and availability of hospital beds and ventilatory support (Bedford et al., 2020).

Besides the consequences to public health and the thousands of lives lost, the debate on measures to combat the new coronavirus in Brazil points to a challenging reality in terms of judicialization.

Judicialization is a phenomenon characterized by the activation of the Judiciary by citizens when they feel that their rights have been harmed or threatened. The Federal Constitution of 1988 provides in Article 5, Paragraph XXXV that "the law shall not exclude any injury or threat to a right from the consideration of the Judicial Power" (BRASIL, 1988). However, there are many criticisms concerning judicialization. Among them are criticisms regarding situations in which Judicial Power is provoked to decide on issues that interfere in the execution and planning of public policies, which are a constitutional attribution of the Executive Power. A judicial decision may compromise the execution of other policies due to the displacement of resources (LEITÃO et al., 2014). When the Executive and the Judicial Power clash in favor of the right to health, there is an impasse, explained by Minister Gilmar Mendes, when saying that the judicial decisions present "a strong point of tension before the elaborators and executors of public policies, who see themselves compelled to guarantee the provision of social rights of the most diverse nature, often contrasting with the policy established by governments for the health sector and beyond budgetary possibilities" (SANTOS; SANTOS; LIMA; et al., 2017).

The Executive Power is responsible for elaborating and managing public policies. Thus, managers of Brazilian states and municipalities started a race to expand hospital beds, acquire materials necessary for the treatment of COVID-19, and decree social isolation to prevent the spread of the 
virus through close contact between people. In this context, the judicialization of the new coronavirus developed, with an impact on public policies developed by the Executive Power (SANTOS, 2020). We are facing an Administrative Law problem, as will be explained below.

Law as science is stratified into two major areas, namely Public Law and Private Law (JURÍDICA, 2020). Administrative Law is the branch of Public Law that, according to Di Pietro (2016), "has as its object administrative bodies, agents, and legal entities that make up the Public Administration, the non-contentious legal activity that it exercises and the assets that it uses to achieve its ends, of a public nature". Mafra (2005) presents the three objects of Administrative Law as: "the organization of the public administration and the various administrative persons that compose it; the powers and rights of these entities in the performance of the public service; the exercise of these powers and rights, their prerogatives, and administrative or litigation action".

In the coronavirus specific case, the Judiciary has been provoked at times to contain excesses practiced by the Executive Power, which has resulted in questionable restrictions to the exercise of essential activities, or to determine to the Executive Power to promote restrictions, fighting administrative decisions towards relaxation of preventive measures that may cause damage to the population (NUNEZ, 2020). Also, requests to guarantee admission to the ICU (Intensive Care Unit), which may require the availability of respirators and other limited equipment, are already coming before the Judiciary. The judicialization of medications that have not yet proven their efficacy, such as chloroquine, hydroxychloroquine, and ivermectin, is another reality. It is also worth mentioning the requests to suspend the debt of States and municipalities to the Union and financial institutions, with the argument that they need to deal with pandemic issues.

However, there is an understanding that, although the Judiciary does not have the competence to formulate public policies, it can correct its flaws. And if there was a failure in the implementation of a policy, and it is a priority to the health or social goals of the country, the Judiciary has the legitimacy to act. Inadequacy occurs when the Judiciary encroaches on executive powers and becomes a public policymaker (GOMES, 2020). Thus, Aith (2017) presents the existence of articulation between those involved in the implementation of public policies as essential, so that State actions can be effective (AITH, 2017). Therefore, the current moment points to unprecedented conflicts in the Judiciary. Challenges already recognized in the specialized literature add to those imposed by the pandemic. In this context, more than ever, it is necessary to develop and implement public policies aimed at individual health, in the sense of treating infected people, and also for collective health, to avoid the uncontrolled expansion of the disease. 
After only a few months passed since the beginning of the pandemic, it is already possible to perceive a very worrying perspective concerning the multiplication of conflicts of interest of all kinds.

This investigation aims to explore lawsuits within the scope of Administrative Law, related to the COVID-19 pandemic, with a potential effect on public health.

\section{Methods and Techniques}

This is a cross-sectional investigation, in which all the cases related to the COVID-19 pandemic received by the Brazilian Federal Supreme Court (FSC), until May 28th, 2020, under the scope of Administrative Law were analyzed. Besides, a survey was carried out in secondary information sources, through journalistic reports, to understand the actions related to the pandemic that do not reach the FSC.

To enable monitoring of lawsuits related to the pandemic of the new coronavirus, the FSC made the "Painel de Ações COVID-19" available. This panel provides updated data on all lawsuits submitted to the FSC related to the COVID-19 pandemic. It aims to inform and allow society to monitor actions on the topic. The lawsuits are separated into classes and subjects. The data on the website is updated every five minutes. A tool tags such lawsuits as preferential and alerts the judges to make the decision process faster (STF, 2020b). Lawsuits initiated before the start of the pandemic can receive the tag during its course and, therefore, can also be part of the panel.

To complement the information on the lawsuits, data were obtained from the "Relatório de Prestação Jurisdicional -Trabalho Remoto", also from the FSC, on the lawsuits and decisions identified in the COVID Panel and received, archived, and/or which had a decision through remote work (STF, 2020c). This panel was implemented starting March 12th, 2020, the date on which Resolution 663/2020 was issued, which defines the temporary measures to prevent coronavirus adopted by the FSC.

To identify the lawsuits the steps described below and shown in Figure 1 were followed. The first step was the exclusion of lawsuits that had no decision since the decision was used to define the subject of the process in later stages of selecting the ones to be studied. In the second stage, the lawsuits that corresponded to Habeas Corpus were removed, as they are not part of the scope of the work, since it is a Criminal Law subject. In the third step, those who had "Administrative Law" as their main or complementary subject were selected, as detailed below. 
Figure 1 - Flowchart of the lawsuits included in the study.

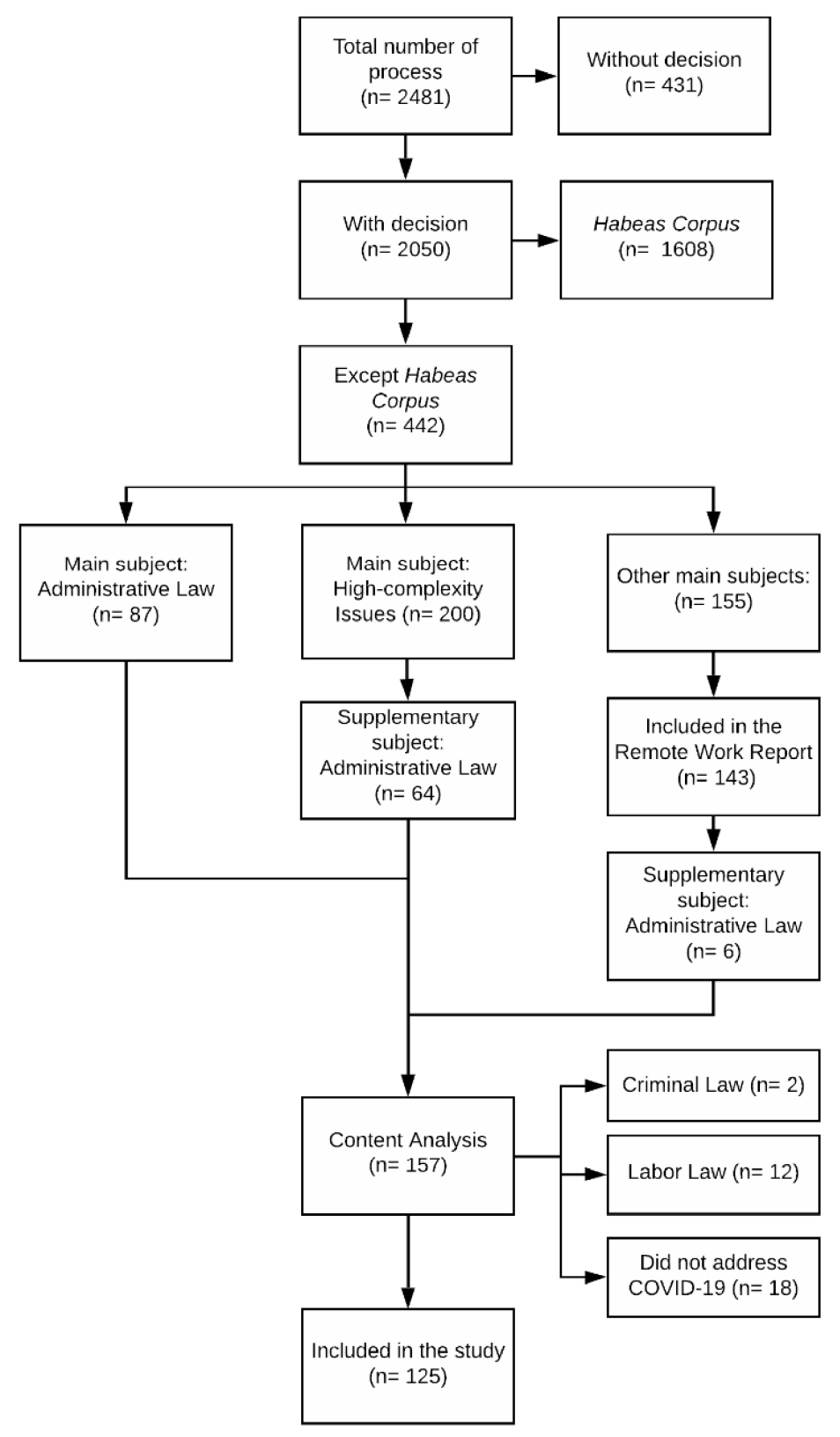

Source: prepared by the authors.

Since the COVID Panel database provides only the main subject of the lawsuits, after the selection of lawsuits with the main subject "Administrative Law", we proceeded to the fourth step, which was the identification of the lawsuits that had this branch of law as a complementary subject. For this, two strategies were used: for the lawsuits with the main subject "Issues of High Complexity, Great Impact, and Repercussion", the complementary subject was identified through manual 
consultation, process by process, on the FSC website. For the other law branches, with a lower probability of having legal lawsuits of interest to the study, the complementary subject was analyzed only among those received or with decisions rendered through remote work. For these, it was not necessary to perform manual analysis since the information was systematized in the Remote Work Panel.

The fifth and final step of selection was identifying the subject of the lawsuits according to the decisions, manually surveyed in the FSC inquiry area. In this phase, content analysis was carried out, in the thematic modality, according to the typology of Badin (2011), to categorize the lawsuits and group them by similarity. Although they were classified as "Administrative Law" in the COVID Panel, those lawsuits mainly dealing with labor law issues, criminal law issues, or that had no direct relation to the pandemic were excluded. It is important to note that the areas of law relate to each other, so there may be, for example, administrative law lawsuits that intersect with labor law. The choice of this research was to select the administrative lawsuits within the scope of its fundamental precept of the primacy of the public interest over the private one.

The following variables were analyzed: procedural classes groups, procedural classes, main subject, assessment date (process start date), time until the first decision (number of days between the assessment date and the date of the first decision), decisions, group of decisions (final decision, interlocutory, internal appeal, and preliminary injunction), and the total number of cases archived remotely. Since a lawsuit can have several decisions, archiving is the event that marks the end of the process.

As previously explained, not all actions related to COVID-19 reach the FSC, with a vast number of actions and decisions in the State Courts. To research a certain Court to obtain actions that deal with a specific theme, a jurisprudential inquiry is made on the respective website. It happens that the jurisprudential inquiry through keywords only covers the legal actions that present terminative decisions. It is difficult to find the legal lawsuits that are in progress, as it is not possible to find them through keywords, like in the jurisprudential research, requiring knowledge of their specific data to find them.

Then, a survey was carried out in secondary information sources, through journalistic reports, to understand actions related to the pandemic that do not reach the FSC. The chosen source was the "Consultor Jurídico" website (https://www.conjur.com.br/), because it is one of the largest legal news portals in the country and allows filtering the news by law area. Journalistic media from a specific source was adopted, as well as the study by Castanheira, Faulhaber, and Gerschman (2018) as a proxy for the behavior of the media in general. Reports published up to $06 / 16 / 2020$ 
were collected. The portal's search tool was used to filter articles with the term "COVID" and related to the Administrative Law Area. For thematic categorization of reports, the content analysis technique was also used (Badin, 2011). The charts were made using Microsoft Excel 2010®, with the exception of the boxplot, which requires more specific analysis resources and, therefore, it was built with the aid of the ggplot2 package of software R, version 4.0.0.

\section{Results}

After consulting two sources for the lawsuits that reached the FSC ("Painel de Ações COVID-19" and "Relatório de Prestação Jurisdicional -Trabalho Remoto"), 2,481 different lawsuits were found. Out of the 2,050 that had at least one decision, 1,608 (78.4\%) were from Habeas Corpus and were excluded from the subsequent analysis (Figure 1).

Out of the 442 remaining cases, 87 had "Administrative Law" as the main subject and remained in the study. Also, 200 had as their main subject "Issues of High Complexity"; 64 were selected due to the identification of the complementary subject "Administrative Law". Out of the 155 lawsuits with other main subjects, six were selected because they are in the Remote Work Report and have a complementary subject "Administrative Law" (Figure 1).

Altogether, 157 lawsuits were included in the content analysis. Out of these, 33 were excluded for referring to the subject "Criminal Law" ( $n=2)$, to issues of "Labor Law" ( $n=12)$, or for not addressing issues related to COVID-19 ( $n=18)$ (Figure 1). The remaining 125 cases were classified into seven categories, as shown in Table 1. Most of them (68\%) refer to the "Restrictive Measures" and "Budget" categories (Table 1). 
Table 1 - Description and frequency distribution of lawsuits selected for the study, according to categories identified in the content analysis, 2020.

\begin{tabular}{|c|c|c|}
\hline Category & Description & n (\%) \\
\hline $\begin{array}{l}\text { Restrictive } \\
\text { Measures }\end{array}$ & $\begin{array}{l}\text { These deal with quarantine, restrictions to commerce } \\
\text { and transport services, limitations in freedom of } \\
\text { movement for the population, "Lockdown", the campaign } \\
\text { "Brazil cannot stop" and others }\end{array}$ & $43(34 \%)$ \\
\hline Information & $\begin{array}{l}\text { These are actions that deal with data sharing by } \\
\text { telecommunications companies during COVID-19, } \\
\text { restrictions in the Information Access Law and even } \\
\text { information about the President's COVID-19 test }\end{array}$ & $10(8 \%)$ \\
\hline Budget & $\begin{array}{l}\text { These address budgeting issues, entities that ask for } \\
\text { debt suspension with the Union or with banks due to the } \\
\text { pandemic, to use these resources in the fight against } \\
\text { COVID-19, the Constitutional Amendment about the } \\
\text { "war budget", the COVID-19 emergency aid, the default } \\
\text { on payment of electricity service, and the allocation of } \\
\text { funds for COVID-19 actions, among others }\end{array}$ & $42(34 \%)$ \\
\hline $\begin{array}{l}\text { Accountability of } \\
\text { Public Officials }\end{array}$ & $\begin{array}{l}\text { Actions dealing with Provisional Measure } 966 \text {, which } \\
\text { seeks to exempt some responsibilities of public officials } \\
\text { for acts carried out during the pandemic }\end{array}$ & $8(6 \%)$ \\
\hline Servers & $\begin{array}{l}\text { Actions covering topics related to applications for public } \\
\text { positions, selection process and creation of } \\
\text { commissioned positions in the context of the pandemic }\end{array}$ & $2(2 \%)$ \\
\hline Procedural & $\begin{array}{l}\text { Actions related to changes in procedures due to the } \\
\text { pandemic, such as teleworking, suspension or change of } \\
\text { deadlines, online hearings, postponement of the } \\
\text { National Examination of Middle School, proceedings in } \\
\text { Congress }\end{array}$ & $18(14 \%)$ \\
\hline Health & $\begin{array}{l}\text { Actions on single-line processes, regulation of ICU beds } \\
\text { and supplies for individual protection and treatment of } \\
\text { COVID-19. }\end{array}$ & $2(2 \%)$ \\
\hline
\end{tabular}

Source: Prepared by the authors, with data from the Federal Supreme Court (FSC).

The cumulative frequency of lawsuits in these two categories and the others grouped can be seen in Figure 2. It is observed that, on April 1st, the most frequent category referred to "Budgets" (38\%) and "Other categories" (36\%). From this date until April 15th, the "Budgets" category grew more rapidly than the others, while the lawsuits in "Other Categories" stabilized. On April 15th, "Budgets" and "Other Categories" accounted for $44 \%$ and $27 \%$ of total cases, respectively. The "Restrictive 
Measures" category has grown almost linearly since March 23rd, when restrictive measures were first enacted and became the most frequent group (35\%) on May 25th.

Figure 2 - Temporal distribution of lawsuits related to restrictive measures, budget and other categories according to the date of inclusion, COVID Panel and Remote Work Panel, 2020.

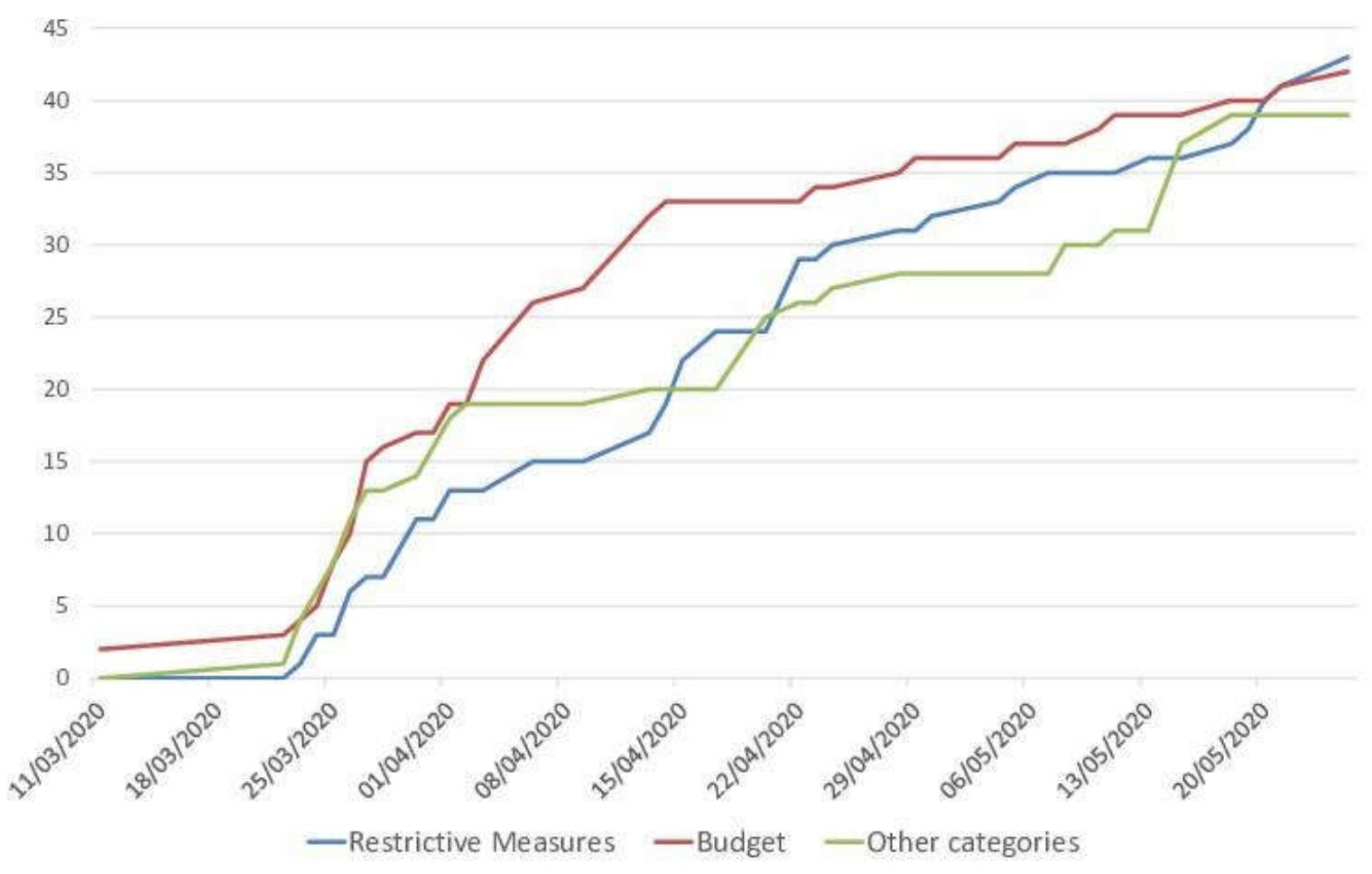

Source: Prepared by the authors, with data from the Federal Supreme Court (FSC).

Note: To improve visualization, a legal process included in 12/03/2019 was excluded.

In the "Budget" category, at least $50 \%$ of the first decisions were made on the same day or on the day after the assessment date. The median time to the first decision was less than five days for all categories studied. Besides, at least $75 \%$ of cases received the first decision in less than ten days. (Figure 3). 
Figure 3 - Boxplot of the time until the first decision (number of days between the date of inclusion and the date of the first decision) for lawsuits related to restrictive measures, budgets and other categories, 2020.

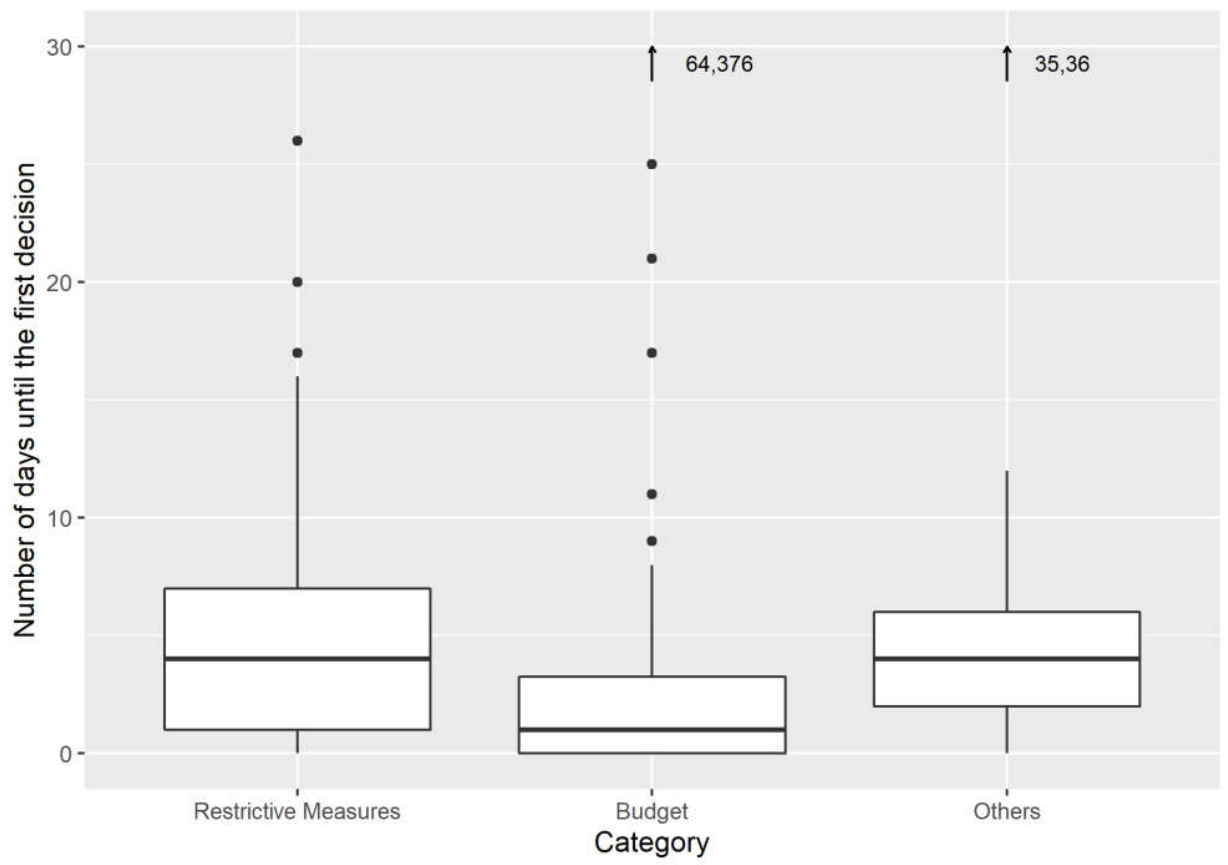

Source: Prepared by the authors, with data from the Federal Supreme Court (FSC).

Note: The arrows indicate lawsuits with time until the first decision over 30 days and the values correspond to the number of days observed.

The majority (81.4\%) of the lawsuits in the category "Restrictive Measures" asked the FSC to deliberate about the flexibilization actions established by States and municipalities (permission, limitations or closings in the commerce and transportation operation). Out of these actions on flexibility, $54.3 \%$ were requests for opening, and the other $45.7 \%$ were requests for the closure of establishments and limitations on the movement of people. The lawsuits requesting opening were almost entirely brought by representatives of the private sector or organizations, such as the Brazilian Association of Car Rental Companies, the National Confederation of Transport, the National Confederation of Tourism, Retail Trade Unions, or Religious Organizations. These lawsuits called for greater flexibility concerning the opening of various categories of commerce, such as convenience stores, law firms, gyms, gymnastics centers, and on-site religiousactivities. On the other hand, other lawsuits requested greater rigidity in restrictive measures, including: prohibiting productive activity and movement of people, by any means; prohibiting campaigns for a return to their full activities or to minimize the severity of the new coronavirus pandemic; and 
lawsuits against the federal government, because of the advertising campaign "Brazil cannot stop".

In the "Budget" category, there were lawsuits to suspend debt with the Union by the States of Acre, Amazonas, Rondônia, Pará, Rio Grande do Norte, Maranhão, Paraíba, Sergipe, Pernambuco, Bahia, Mato Grosso, Mato Grosso do South, Espírito Santo, São Paulo, Rio de Janeiro, Santa Catarina, and Paraná. Some municipalities have also requested debt suspension. There were also lawsuits filed by the states of Maranhão, Tocantins, and Mato Grosso to reallocating financial resources already earmarked for to tackle the COVID-19 pandemic (prevention, containment, and mitigation actions), through its application in other health actions, social assistance, and public security.

We also found lawsuits questioning Constitutional Amendment 106, of 2020, known as the "War Budget", which aims to facilitate federal government spending in combating the pandemic by separating pandemic spending from the Union general budget.

The search on the "Consultor Jurídico" website initially brought 436 news items, of which 252 $(57.8 \%)$ were not selected. Most of the excluded news referred to debates and conferences via the web $(21.0 \%)$, resolutions related to remote work in the Judiciary organs (18.2\%), and opinion articles (15.1\%) (Figure 4). 
Figure 4 - Absolute and relative frequency of journalistic news not included in the study, 2020.

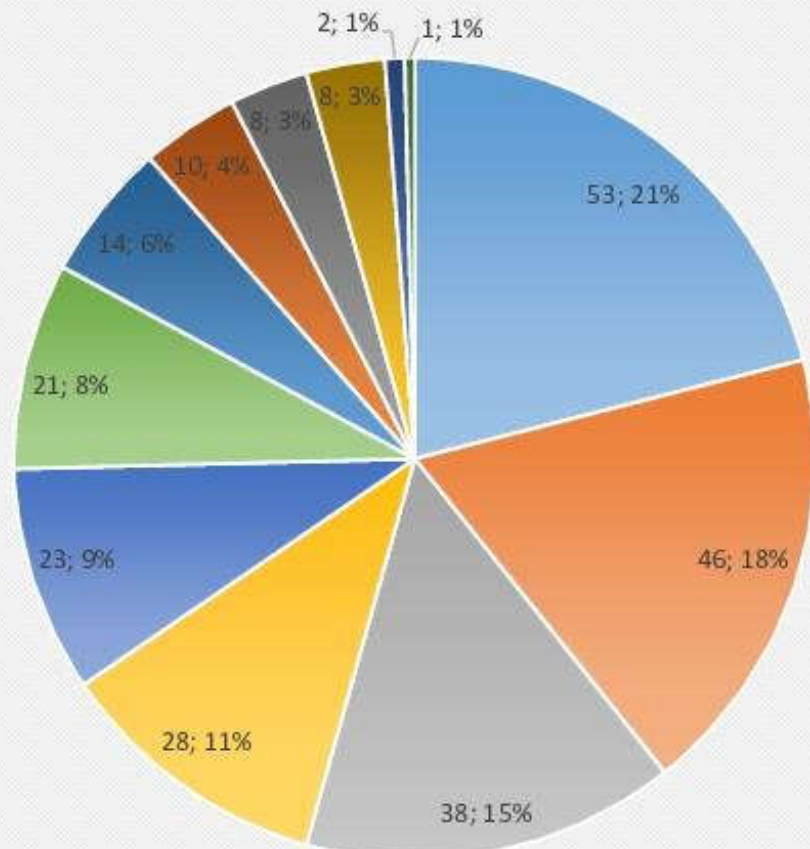

- Debate

m Rules of remote work

= Opinion article

Not related to Covid

m Actions of Executive

= Manifestations and recommendations

- Labor Law

m Panels and information sources

m Law approval

- Allocation of funds from judiciary to Covid

- Criminal Law

Source: Prepared by the authors, with information obtained from the "Consultor Jurídico" website.

Considering the $184(42.2 \%)$ selected news, we found 84 (45.6\%) referring to restrictive measures, $29(15.8 \%)$ referring to the health area, $25(13.6 \%)$ regarding budgets, and $24(13.0 \%)$ on procedures (Figure 5). Also, 33 (18.0\%) news had lawsuits judged by the FSC, six (3.3\%) by the Superior Court of Justice (SCJ), and two (1.1\%) by the General Accounting Office (GAO). Among the 143 that were from the State Courts, Jurisdiction or Districts, $68(47.6 \%)$ were from São Paulo and 31 (21.7\%) from Rio de Janeiro. In addition to these, administrative lawsuits related to COVID-19 were reported in 11 States, such as the Federal District $(n=8)$, Pernambuco $(n=8)$, and Rio Grande do Sul (n=7). 
Figure 5 - Absolute and relative frequency of journalistic news included in the study, 2020.

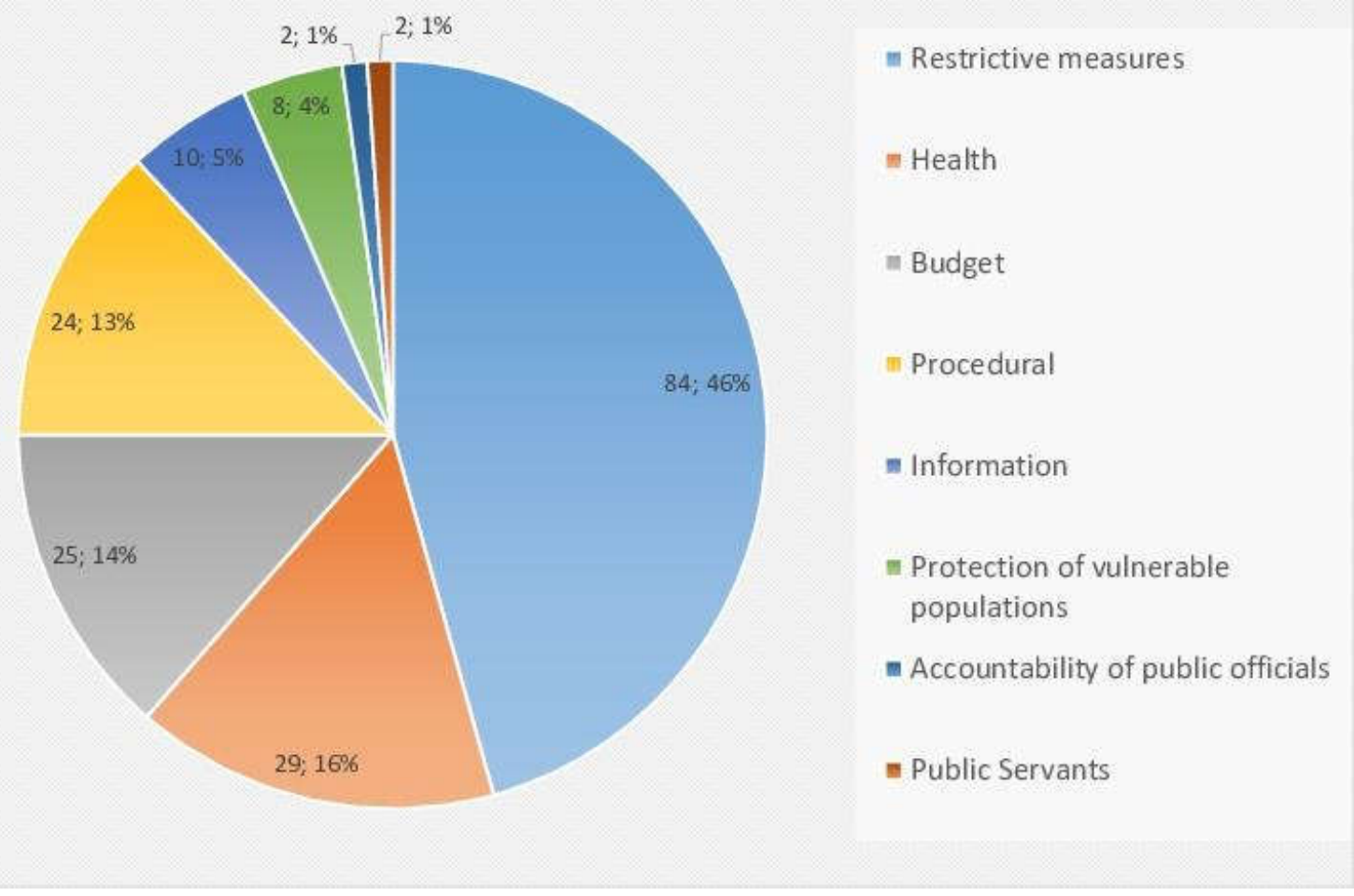

Source: Prepared by the authors, with information obtained from the "Consultor Jurídico" website.

Among the news about restrictive measures $(n=84)$, a large part refers to actions by the Federal Prosecution Service (FPS) and the Public Defender's Office (PDO) against the States and Municipalities in order to adopt a lockdown, to suspend measures to relax social isolation, or to adopt strategies to tackle the new coronavirus. In this situation and in those dealing with competing competences between the federal entities in the FSC $(n=20)$, in general, the Judiciary has acted to ensure that the restriction measures are met $(n=15)$. The adoption of lockdown was requested in the states of Amazonas, Pernambuco, and Maranhão. The lawsuits against the relaxation of social isolation were filed in Pará, Rio de Janeiro (RJ), Duque de Caxias (RJ), Búzios (RJ), Ribeirão Preto (SP), Santos (SP), São José dos Campos (SP), among others. News about lawsuits against the quarantine flexibilization has been disseminated since April 1st.

Concerning health administrative issues $(n=29)$, the Judiciary acted mainly in disputes between the Union and the other entities of the Federation about the ownership of respirators $(n=9)$. Most of the cases were presented by municipalities that did not receive the equipment because the manufacturers claimed that they could not guarantee the supply, in the face of the Union production requirement of 180 days. In general, the Judiciary's decisions ensured that the respirators stayed in the municipalities. 
Also important were lawsuits requesting an increase in hospital beds in the public network $(n=8)$, all of which were filed in the State of Rio de Janeiro. These lawsuits requested hiring more health professionals for hospitals with unused beds because of the lack of professionals and to transfer beds from federal hospitals to the state and municipality Unified Health System (UHS). Also, disputes have been reported between the public and private systems $(n=6)$, most of them related to Law 13.979/2020 (Brazil, 2020), which advances requests for goods and services, both from individuals and legal entities, to combat the pandemic $(n=4)$. Lawsuits with requests for application of this law for the acquisition of masks by the Government of Paraíba and equipment by the municipality of Porto Alegre were observed, as well as actions in the FSC. In one of them, the National Health Confederation (NHC), which represents health service providers at the national level, requested the creation of rules to regulate and control requests made by the government.

\section{Discussion}

These findings show the complex scenario and challenges of judicialization of public policies during times of COVID-19. The linear trend of growth in the accumulated number of lawsuits on restrictive measures, with no signs of stabilization, points out that this phenomenon will continue to be relevant for the Judiciary in the coming months. These challenges will have an uncertain duration, since scientific evidence points to a worrying future scenario, in which new waves, with increasing cases and deaths, may be recurrent until the creation of an effective vaccine (FERGUSON et al., 2020; SCHUCHMANN ET AL., 2020). Therefore, the pandemic will affect thousands of people in Brazil in the short, medium, and long term, and will have effects in all areas of law.

Among all the decisions analyzed, the one with the greatest impact is The Direct Action of Unconstitutionality (DAU) No. 6,341/2020 (STF, 2020a), which affected several other lawsuits, declaring the role of health authorities and public managers of States and municipalities as constitutional and legal in the adoption of normative and administrative measures to face the pandemic, without exempting the federal government from its responsibilities.

The STF Plenary decided that states and municipalities, within the scope of their competencies and in their territory, can adopt restrictive measures to commerce and in the intercity and local movement during the emergency state resulting from the pandemic, without the need for authorization from the Ministry of Health to decree isolation, quarantine, and other measures. 
As a result of this decision, it is possible to observe great heterogeneity in the mitigation measures adopted, which justifies why actors interested in economic activities resort to judicialization in territories where the measures are more restrictive, as well as the opposite to increase the restriction or duration of measures in those places where flexibilization started to occur in unfavorable health conditions. It is also important to highlight the impact of the federal government's lack of coordination and guidance as the national manager of the Unified Health System (UHS) on the course of the epidemic in Brazil.

This scenario highlights the fluidity of the limit between politics and justice in the contemporary world, observing a transfer of political power to judges and courts, with important changes in the language, arguments, and society participation mode (ALVES, RAMOS, DELDUQUE, 2020).

The urgency triggered by the pandemic led the Judiciary to become the protagonist of restrictive measures, such as the unprecedented decision, which determined that the Maranhão State government should declare lockdown, based on the constitutional recognition of health as a fundamental social right (TJMA, 2020), and imposing a series of obligations on the defendants, without knowing whether the local political agents would be possible to organize and support these obligations (Alves, Ramos, Delduque, 2020).

In face of a health crisis of such unpredictability and with important between different sectors that are directly or indirectly affected by the restrictive measures, the implementation of pandemic mitigation policies while preserving the constitutional autonomy of the federation entities and the observance of the distribution of Powers is a great challenge.

For Brazilian public health, the struggle between a national constitutionally based policy and federative autonomy has been part of the daily management of the UHS since its creation. Cyclical movements of decentralization and new centralization are taking place. Municipalization, which proved to be a great virtue, also led to the difficulty of organizing regional health systems, often due to the omission of states and the lack of coordination by the national manager, thus generating a reality of dispersed and differentiated actions in volume and quality at the local level. This dilemma of UHS was observed in the pandemic, and part of its discussion reached the Judiciary.

The moment is even more complex in Brazil in the face of a political crisis in which there is no convergence between political leaders and between the three powers on how to face the pandemic. The UHS tradition of having spaces built to seek consensus between the three management levels has become a challenge in pandemic times. So, it is not surprising that the Judiciary is called upon to manage policy, as the results of this study showed. Based on a false 
opposition between health and economic interests, lawsuits with competing interests became evident in the ongoing discussions in the country.

Despite pressure from different sectors of the economy, current evidence points to the need for governments to maintain and alternate different measures of social isolation and restriction of population mobility (SCHUCHMANN ET AL., 2020; DESHWAL, 2020). The projections suggest a major economic crisis, regardless of the level of adoption of isolation measures: large, reduced, or even absent. What differentiates these measures is the possibility of decreasing mortality from the pandemic (SCHUCHMANN ET AL., 2020). It is important to remember that almost $70 \%$ of the lawsuits studied were about mobility restriction, which is consistent with the importance that these measures have in facing the pandemic.

On the other hand, regardless of the lack of national coordination, a fact that should be better analyzed throughout history is that the confrontation of the pandemic in Brazil has shown the importance and vitality of a universal, comprehensive, and enormously decentralized health system, albeit with enormous difficulties and insufficiencies in the network and human and financial resources. There would be no use in a judicial decision assigning obligations to the municipalities, for example, in terms of social isolation measures, if these same municipalities were unable to start a series of actions to control the pandemic and to care for their population.

Another recurring discussion in the FSC lawsuits was the request from States and municipalities to suspend their debts, justified by the need to use these resources to tackle the new coronavirus. In the news, this theme was also present, and most of the lawsuits resulted in the debt suspension by the Judiciary.

Lawsuits with the same objective flooded the FSC, supporting the need for the inclusion of Parliament in this debate. The response was the publication on May 27th, 2020 of Complementary Law No. 173, which established the Federative Program to Combat Coronavirus. Among the Program's initiatives was the suspension of debt payments contracted between the Union and the States and municipalities, the delivery of Union resources via financial assistance to the States, the Federal District, and municipalities in 2020, and in actions to combat the pandemic (LC $N^{\circ}$ 173, 2020).

The investigation of journalistic reports allowed verification that the judicialization related to COVID-19 also represents an important phenomenon in the Jurisdictions and Courts of several States. Actions on COVID-19 are recent, and most have not yet had final decisions. However, the 
journalistic reports analyzed indicated the existence of injunctions about issues involving COVID19 in several States in Brazil. Soon, this can be seen through jurisprudence research.

Besides the restrictive measures, the reports indicate that judicialization related to the health area has been gaining space in the Jurisdictions and Courts of the different States. Among the orders are the acquisition of equipment necessary to face the COVID-19, such as respirators and masks, and an increase in the number of beds and professionals. The already known weaknesses of UHS have gained even more visibility during the pandemic.

Health, inserted in the Brazilian Constitution as a citizen's right, is a central and frequent theme in political and judicial conflicts. The complexity of the health care system, which encompasses a great diversity of actors in the public and private sectors, as well as several regulatory entities and numerous legal provisions, results in a conflicting field that has promoted the growth, since the 1990s, of judicialization of health care.

As it exposes weaknesses in access to public health policies, highlighting health care gaps, judicialization instigates a necessary debate. It leads to the reaching of solutions, such as the viability of beneficial therapeutic alternatives previously not available in UHS, or the incorporation of new protocols and therapeutic guidelines, increasing the range of treatment options (Neto et al., 2012).

However, the increase in the judicialization of health, especially in the context of a pandemic, raises important concerns about the budgetary impact, particularly for UHS. Judges tend to disregard the impact of their decisions and understand that all federation entities can be equally responsible for providing any patient request. For the Judiciary, in general, issues related to public budgeting, such as the scarcity of resources and lack of expenditure forecast, as well as nonbelonging of the medication requested to UHS drug lists, do not justify denying medical treatment since it finds support in the right to health guaranteed by the Federal Constitution. This culture of granting health requests by the Brazilian Judiciary is considered one of the incentives for increasing the number of lawsuits seeking medical care based on the constitutional right to health (Wang et al., 2014).

Recently, the National Supplementary Health Agency (NSHA) included new coronavirus detection tests in the Compulsory Coverage Procedures List for health insurance plans. The inclusion of serological tests took place after a lawsuit. Subsequently, the conquest of this lawsuit was annulled, and they are now awaiting the completion of a public consultation to deliberate on this topic.(ANS, 2020). Although the inclusion of new tests took place along with the disclosure of the Usage Guidelines (UG), fear of the disease and the population's lack of knowledge about when 
the tests should be requested and performed could generate many conflicts between the health insurance carriers and their customers, including scope for legal actions related to this topic. It is also worth mentioning that these changes, although important in the context of the pandemic, can generate a large volume of costs not expected by carriers, especially in the long run.

An important point to highlight in this work was the great methodological effort required to classify the subjects of the lawsuits and to identify those related to the new coronavirus, which is a challenge found by the group in other studies of judicialization of health. Standardization of the mandatory data included in the initial petitions, including the appropriate subject classification, would facilitate the study of the judicialization of health. In the specific case of judicialization involving the new coronavirus, the panels made available by other public or private organizations could organize the lawsuits using a classification model similar to the one adopted in this article, to facilitate the jurimetrics analysis by research groups interested in the topic.

\section{Final Considerations}

Judicialization during times of COVID-19 tends to increase and, possibly, have consequences for public health and for the economy of all countries over a long time period.

In Brazil, lawsuits related to restrictive measures, budgeting issues, and health aspects have been reaching the Judiciary in large numbers even a few months after the beginning of the pandemic.

The increase in judicialization points to the urgency of efficient public policies to face the pandemic and its health and social consequences. Regarding budgeting issues, the consistency of actions requesting the same object was responded by Complementary Law 173. However, disputes related to restrictive measures and health-related issues are, so far, without robust political proposals, or with proposals that do not fully approach solutions or, at least, alternatives to minimize their impacts.

In this way, judicialization was able to bring a diagnosis of failures in public policies to face the demands arising from the pandemic. It had the importance of driving the creation of law, and it can boost several other actions both from the Legislative and the Executive, to mitigate these problems. This demonstrates the importance of observing the responses brought by the judicialization, and of the dialogue between the three branches of the Republic, to deal with the pandemic demands and other social demands better. 
Thus, the pandemic of the new coronavirus and its consequent judicialization has posed new challenges for a country like Brazil, which remains a country with one of the highest volumes of health lawsuits in the world.

\section{References}

AITH, F.M.A. Efetivação do Direito à Saúde em seus múltiplos caminhos. Novas institucionalidades para a solução de conflitos em saúde. Apud BUCCI, M. P. D. e DUARTE, C. S. Judicialização da saúde: a visão do poder executivo. São Paulo: Saraiva, 2017 ANS. Agência Nacional de Saúde Suplementar. Nota de esclarecimento Coronavírus. 14, jul. 2020. Available from: <http://www.ans.gov.br/aans/noticias-ans/coronavirus-covid19/coronavirus-todas-as-noticias/5708-nota-de-esclarecimento> Accessed: 07, ago. 2020.

ALVES, S.M.C.; RAMOS E.M.B.; DELDUQUE M.C. Lockdown by court order: an (un)necessary measure? Cad. Saúde Pública 36 (6) 17, jun. 2020. https://doi.org/10.1590/0102-311X00116020 BARDIN, L. Análise de conteúdo. Lisboa. 2011. 279p.

BRASIL. Constituição (1988). Constituição da República Federativa do Brasil. Available from: <http://www.planalto.gov.br/ccivil_03/constituicao/constituicaocompilado.htm> Accessed: 23, jun. 2020.

BRASIL. Lei Complementar $n^{\circ} 173$, de 27 de maio de 2020. Estabelece o Programa Federativo de Enfrentamento ao Coronavírus SARS-CoV-2 (Covid-19), altera a Lei Complementar n 101, de 4 de maio de 2000, e dá outras providências Diário Oficial da União 28, mai 2020 . Available from: <http://www.in.gov.br/en/web/dou/-/lei-complementar-n-173-de-27-de-maio-de-2020258915168>. Accessed: 25, jun. 2020.

CASTANHEIRA, D.; FAULHABER, C.; \& GERSCHMAN, S. (2018). O papel da mídia na construção da agenda governamental para o SUS no Rio de Janeiro. Revista Eletrônica de Comunicação, Informação e Inovação em Saúde, 12(3).

doi:https://doi.org/10.29397/reciis.v12i3.1455

BEDFORD, J.; ENRIA, D.; GIESECKE, J.; et al. Covid-19: towards controlling of a pandemic. Lancet 2020; published online March 17. https://doi.org/ 10.1016/S0140-6736(20)30673-5.

DESHWAL, V.K. Covid 19: A comparative study of Asian, European, American continent. Int J Sci Res Enginee Dev., 2020; 3(2): 436-40. 
DI PIETRO, M. S. Z. Direito Administrativo. 29. ed. Imprenta: Rio de Janeiro, Forense, 2016. FERGUSON, M.N.; et al. Impact of non-pharmaceutical interventions (NPIs) to reduce Covid19 mortality and healthcare demand 2020. Available from:

<https://www.imperial.ac.uk/media/imperial-college/medicine/ sph/ide/gida-fellowships/ImperialCollege-Covid19-NPI-modelling-16-03-2020.pdf> Accessed: 08, jun. 2020.

GOMES, N. Judicialização de política pública e o atual cenário nacional da Pandemia Coronavírus. 03/2020. Available from: <https://jus.com.br/artigos/80599/judicializacao-depolitica-publica-e-o-atual-cenario-nacional-da-pandemia-coronavirus> Accessed: 23, jun. 2020. JURÍDICA, E. Ramos do Direito. Available from: <http://www.enciclopediajuridica.com/pt/d/ramos-do-direito/ramos-do-direito.htm> Accessed: 23, jun. 2020

LEITÃO, L.C.A.; et al. Judicialização da saúde na garantia do acesso ao medicamento. Revista de Salud Publica, v. 16, n. 3, p. 360-370, 2014.

MAFRA, F. Relações do Direito Administrativo com outros ramos do Direito e das Ciências Sociais. 28/02/2005. Available from: <https://ambitojuridico.com.br/cadernos/direitoadministrativo/relacoes-do-direito-administrativo-com-outros-ramos-do-direito-e-das-cienciassociais/> Accessed: 23, jun. 2020

CAMPOS NETO, O.H.; et al. Médicos, advogados e indústria farmacêutica na judicialização da saúde em Minas Gerais, Brasil Rev de Saúde Pública. 2012; 46: 784-790.

NÚÑEZ, L.P.S. Combate à Pandemia Covid-19 e repartição Constitucional- competências in: MACEDO, ELAINE HARZHEIM. A Judicialização dos conflitos e a Pandemia do Covid-19. 2020. SANTOS, Matheus Teodoro Ramsey. Judicialização da administração pública em meio à pandemia. Jun, 2020. Available from: < https://www.jota.info/coberturas-especiais/inova-eacao/judicializacao-da-administracao-publica-em-meio-a-pandemia-02062020> Accessed: 23, jun. 2020

SANTOS, M. W. B.; SANTOS, A. V.; LIMA, C. M. M. A.; et al. O caso da Fosfoetanolamina sintética. Judicialização com risco à Saúde. Apud BUCCI, M. P. D. e DUARTE, C. S. Judicialização da saúde: a visão do poder executivo. São Paulo: Saraiva, 2017 SCHUCHMANN, A. Z.; SCHNORRENBERGER, B. L.; CHIQUETTI, M. E.; GAIKI, R. S.; RAIMANN, B. W. e MAEYAMA, M. A. (2020). Isolamento social vertical X Isolamento social horizontal: os dilemas sanitários e sociais no enfrentamento da pandemia de Covid-19. Brazilian Journal of Health Review, 3 (2), 3556-3576. doi: https://doi.org/10.34119/bjhrv3n2-185 
STF. Ação Direta de Inconstitucionalidade (ADI) 6341. 2020a. Available from:

<http://portal.stf.jus.br/processos/detalhe.asp?incidente=5880765> Accessed: 07, jun. 2020

STF. Painel de ações Covid-19. 2020b. Available from:

<https://portal.stf.jus.br/noticias/verNoticiaDetalhe.asp?idConteudo=440336\&ori=1> Accessed:

07, jun. 2020.

STF. Relatório de Prestação Jurisdicional - Trabalho Remoto. 2020c. Available from:

<http://www.stf.jus.br/portal/cms/verNoticiaDetalhe.asp?idConteudo=440719> Accessed: 08, jun. 2020.

TJMA. Tribunal de Justiça do Maranhão. Ação Civil Pública - processo no 0813507 -

41.2020.8.10.0001. Available from: <https://pje.tjma.jus.br/pje/ ConsultaPublica/listView.seam> Accessed: 02, mai. 2020.

WANG D.W.L.; VASCONCELOS N.P.; OLIVEIRA V.E.; TERRAZAS F.V. Os impactos da judicialização da saúde no município de São Paulo: gasto público e organização federativa. Rev. Adm. Pública. 2014;48(5):119-1206.

ZHU, N.; ZHANG D.; WANG W.; LI X.; YANG B.; SONG J. ET AL. A Novel Coronavirus from Patients with Pneumonia in China, 2019. N Engl J Med. 2020;382(8):727-33. doi: 10.1056/ NEJMoa2001017.

\section{lara Veloso Oliveira Figueiredo}

Orcid: https://orcid.org/0000-0002-0927-859X Lawyer, Master's degree in Public Health, PhD student in Public Health at IRR/Fiocruz. E-mail: iaravof@gmail.com

\section{Mônica Monteiro de Castro}

Orcid: https://orcid.org/0000-0003-2461-3699

Physician, PhD in Epidemiology and Public Health, Researcher, Executive and Health Consultant. E-mail: monica.castro@fiocruz.br

\section{Gabriela Drummond Marques da Silva}

Orcid: https://orcid.org/0000-0002-1145-3940

Statistician, Researcher at IRR/ Fiocruz, Master's degree in Statistics and PhD in Public Health. E-mail: gabriela.marques@fiocruz.br

Wanessa Debôrtoli de Miranda

Orcid: https://orcid.org/0000-0002-0838-9861 
Nutritionist, PhD in Public Health, Professor at the Federal University of Minas Gerais (UFMG). Email: wanessa.debortoli@hotmail.com

\section{Helvécio Miranda Magalhães Júnior}

Orcid: https://orcid.org/0000-0002-7628-7509

Physician, PhD in Public Health at State University of Campinas (UNICAMP), Researcher at IRR/ Fiocruz. E-mail: helveciomiranda@gmail.com

\section{Rômulo Paes de Sousa}

Orcid: https://orcid.org/0000-0002-3384-6657

Physician, Senior Researcher at Fiocruz and Honorary Associate Researcher at IDS at the University of Sussex. E-mail: romulo.paes@fiocruz.br 